\title{
Identification of Innovation Ideas in Its Development Process
}

\begin{abstract}
After identifying the essence of the term innovation the authors of the paper strive to identify approaches to the innovations development process in companies, and systematize the first part of the innovation process identification of information sources of innovation idea.
\end{abstract}

Keywords: innovation sources, marketing, innovation value chain.

Nustatę termino inovacija esmę, straipsnio autoriai siekia identifikuoti organizacijų požiūrị ị inovacijų vystymo procesą įmonèse ir susisteminti inovacijų proceso pirmajji etapą - inovacijos idèjos identifikavimo informacijos šaltinius.

Raktiniai žodžiai: inovacijos šaltiniai, marketingas, inovacijų vertės grandinè.

\section{Introduction}

In the information century economy is based on knowledge, access to information and productive work. In traditional economy where the main resource was land and in industrial society where the main resource was capital, economic relations and firms' competitive advantages formed on this very base, and the potential of use of human resource capital was not emphasized. Scientists in their latest researches present the term Innovative economics, which describes the current development stage of developed countries. Contemporary global business environment is considered to be too competitive, and the process of implementing innovations is usually time consuming and unsuccessful. However, innovations are the key to economic recovery. This was discovered during the evaluation of recent economic cycles. During the process of analysing sales results this was also concluded among thousands of marketing and brand managers. The increment of employment level is notably faster in companies that are involved in innovative development, in comparison with the

Anda BATRAGA - associate professor at the Faculty of Economics and Managment, University of Latvia. Phone: + 37129224 223. E-mail: anda.batraga@lu.lv.

Liga BRASLINA - mg. oec. of the Faculty of Economics and Managment, University of Latvia. Phone: + 37126599 481. E-mail: liga.braslina2@inbox.lv.

Kaspars VIKSNE - mg. oec. of the Faculty of Economics and Managment, University of Latvia. Phone: +371265 59 228. E-mail: kaspars.viksne@gmail.com 
companies that do not deal with innovations (LU, 2011). It is emphasized that the company's performance and growth cannot be successful in the $21^{\text {st }}$ century unless the company deals with innovations. Innovations are not just about science and technology development anymore. It is emerging to be social-economic category (LU, 2011). Contemporary scientific literature increasingly evaluates factors that affect innovations, especially functions that support microsystems are emphasized. Scientific OECD innovation process describes 3 general stages - invention, innovation and development of a new product. However there is a lack of literature that investigates concrete empirically usable methods that could potentially be applied in micro-environments for innovation creation. In the paper the authors strive to identify the innovations development process approaches in companies, and systematize its first part - innovation idea identification sources of information. Therefore the aim of the paper is to identify and analyse academically offered and practically used innovation process models, focusing on identification of information sources for innovation idea identification; then, based on the findings, to provide an innovation process improved model and synthesis of available information sources. The tasks of the paper: 1) to investigate the essence and content of innovation in the context of innovation process, 2) to identify academically offered and practically used innovation process models, highlighting innovation process beginning stages related with innovation idea identification; 3) to identify and classify innovation idea identification sources of information. The object of the paper research - innovation process. The subject of the paper research - information source. During the paper development the following conventional quantitative and qualitative methods were used: 1) Monological documentation analysis that provides a detailed study of the research object. It is based on comprehensive review of existing scientific literature; 2) Grouping method - development process of homogeneous groups that is based on splitting statistical set into several groups according to common characteristics; 3) Graphical analysis method, which recognizes the existence of coherence among objects and characteristics of these coherences that allows constructing of graphics; 4) Content analysis - systematic evaluation, grouping and interpretation of sources of information form and content. Paper information sources. Theoretical and methodological core is specialized economics literature on innovations, marketing, research and development; local and international scientists' published works, materials of scientific conferences and seminars, legislation of the Republic of Latvia, OECD economics and other international institution provided methodological documents. Delimitations of the research subjects. The research concentrates on innovation process, and on one specific stage of the innovation development process - identification of innovation ideas focused on information sources which could allow the company to gain ideas for potential innovations. In the research there are evaluated only micro-environment factors. The paper is focused on product innovation, but it does not eliminate process, marketing or organizational innovation. In accordance with OECD redaction, product innovation involves new or essentially improved goods or services. Product innovation means significant improvements in 
products technical specifications, various components and materials, existing programmes, or in other functional attributes (OECD, 2005).

Novelty of the paper. Different innovation development processes with various approaches are provided. By taking into account conclusions provided by theoretical sources, and the authors' practical and academic experience, the improved innovation process model is provided. The authors also provide summarized and systematized innovation idea identification sources of information that allow companies to systematically create innovation ideas, hugely enlarging the field of information sources avoiding from application of a single-sided brainstorm method.

\section{Innovation definition and process}

Within the last decade the word "innovation" has become as one of the most over-used words in the industry. There are hundreds of innovation term definitions. OECD (Organisation for Economic Cooperation and Development) defines innovation as a new or significantly improved product, service, process, marketing or organizational methodology implementation. Various methodologies exist for describing innovative process. These methodologies vary among the different industries. Innovation process includes innovation creation, analysing and controlling related functions. The role of innovation process' systems is to ensure efficiency, communication, coordination, collection of experience, and coordination of inter-activities (Davila et al., 2013). OECF innovation process distinguishes 3 main stages - invention, innovation and development of a new product or service.
Factors that affect invention are: education system, research and development (R\&D), organization supportive structures and technological transfer. Factors that affect the development of a new product or service are organization's management, marketing, and available investments (OECD, 2005).

OECD emphasizes the innovation phenomena measurement and identification of collaboration opportunities, innovation process research and potential, paying no attention to studies of the specifics of different industries. Therefore more concrete innovation process analysis schemes are provided by specific industries.

Among many models of innovation process two of the most approbated procesual approaches for the new product development are provided by B. A. Hamilton (1982) and G. Cooper (1993). Even though the idea of both of these models is similar, still some dissimilarity between these approaches can be clearly identified. B. A. Hamilton model (BAH Model provided in Figure 1) was improved by G. Cooper during the applied usage, and later became known as Stage/ Gate Model (Figure 2).

The main difference between these models lies in the management approach. BAH model emphasizes content-conceptual aspect, while Cooper's model concentrates more on New Project Development (NPD) project management, dividing each step into separate project management stages. In the beginning of innovation development process $\mathrm{BAH}$ emphasizes the importance of new product strategy. In scientific literature there are duo-versal assessments at the beginning of the new product strategy importance in innovation process. Some scientists believe that it is a crucial factor for a 


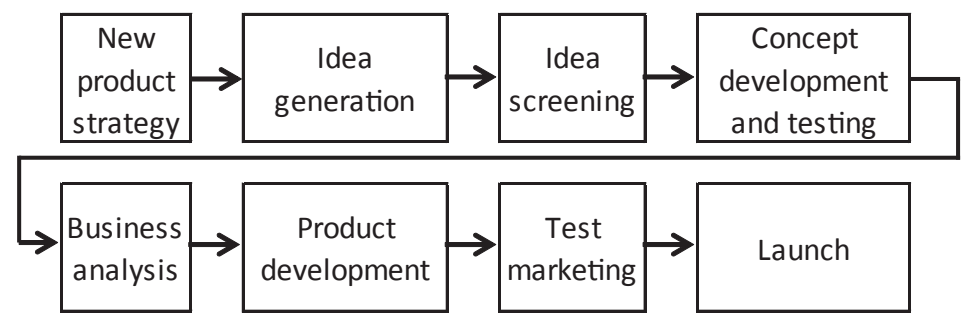

Fig. 1. BAH innovation process model

Source: M. J. Baker and S. Hart (2008).

\begin{tabular}{|c|c|c|c|c|c|c|c|c|}
\hline \multirow{5}{*}{ 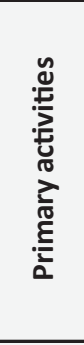 } & $\begin{array}{c}\text { Idea } \\
\text { sources \& } \\
\text { generation }\end{array}$ & $\begin{array}{c}\text { Idea } \\
\text { screening }\end{array}$ & $\begin{array}{c}\text { concept } \\
\text { develop- } \\
\text { ment }\end{array}$ & $\begin{array}{c}\text { Prototype } \\
\text { develop- } \\
\text { ment }\end{array}$ & $\begin{array}{c}\text { Product } \\
\text { manu- } \\
\text { facturing }\end{array}$ & $\begin{array}{c}\text { Commercial- } \\
\text { ization }\end{array}$ & Revise & \multirow{9}{*}{$\begin{array}{l}z \\
\text { 은 } \\
\frac{\mathbf{4}}{3} \\
0 \\
\underline{z} \\
\underline{z}\end{array}$} \\
\hline & GO & GO & $\mathrm{GO}$ & $\mathrm{GO}$ & GO & GO & GO & \\
\hline & Stage 0 & Stage 1 & Stage 2 & Stage 3 & Stage 4 & Stage 5 & Stage 6 & \\
\hline & Gate 0 & Gate 1 & Gate 2 & Gate 3 & Gate 4 & Gate 5 & Gate 6 & \\
\hline & Rework Kill & Rework & $\begin{array}{c}\text { Rework } \\
\text { Kill }\end{array}$ & Rework Kill & $\begin{array}{c}\text { Rework } \\
\text { Kill }\end{array}$ & Rework & Rework & \\
\hline \multirow{4}{*}{ 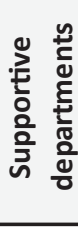 } & Marketing & & & & & & & \\
\hline & Production & & & & & & & \\
\hline & Finance & & & & & & & \\
\hline & Management & & & & & & & \\
\hline
\end{tabular}

Fig. 2. Stage/Gate innovation process model

Source: M. J. Baker and S. Hart (2008).

company to achieve its objectives. Other scientists however perceive it as limitation that may even delay the development of radical innovations. P. Drucker points to significance of the company's management fallacies and inappropriateness in identifying innovation ideas. Periodically analysing the companies' management assumptions of business results, the notable innovation for the company and industry can be revealed. The NPD strategies' strengths are clearly defined as NPD goals, long-term development plan, investment plan, proper resource allocation, and appropriate portfolio management that allow avoiding work overload of $\mathrm{R} \& \mathrm{D}$ department's human resource, and ignorance of time schedule. Creation of NPD strategy also allows to determine investment priorities and to create a list of criteria for innovation ideas. In US Study "The Best Practice Study" in 1997 it was found that $60 \%$ of US companies are using one of "Stage/Gate innovation process" modifications. Despite the fact that the model was created a few decades ago, in 2004 $\mathrm{BAH}$ found that innovation's success is directly based on innovation process and its 
performance in a company (Baker, Hart, 2008).

S. Gopalakrishnan and F. Damnpour offers 5 step model for innovation process which consists of the following stages: 1) generation of idea; 2) project definition; 3) problem solution process; 4) design and improvement; 5) marketing and commercialization (Gopalakrishnan, Damnpour, 1997).

M. Assink provides a conceptual model for disruptive innovations development.
The model consists of 4 procesual stages:

1) problem identification, 2) innovation creation, 3) planning, 4) implementation (Figure 3) (Assink, 2006).

B. Bernstein and P. J. Singh consider innovation process as 4 step process: 1) idea generation, 2) innovation support, 3) Innovation development, 4) innovation implementation (Bernstein, Singh, 2006).

In the context of entrepreneurship P.Drucker offers the following scheme for innovation process (Figure 4) (Swaim, 2010).

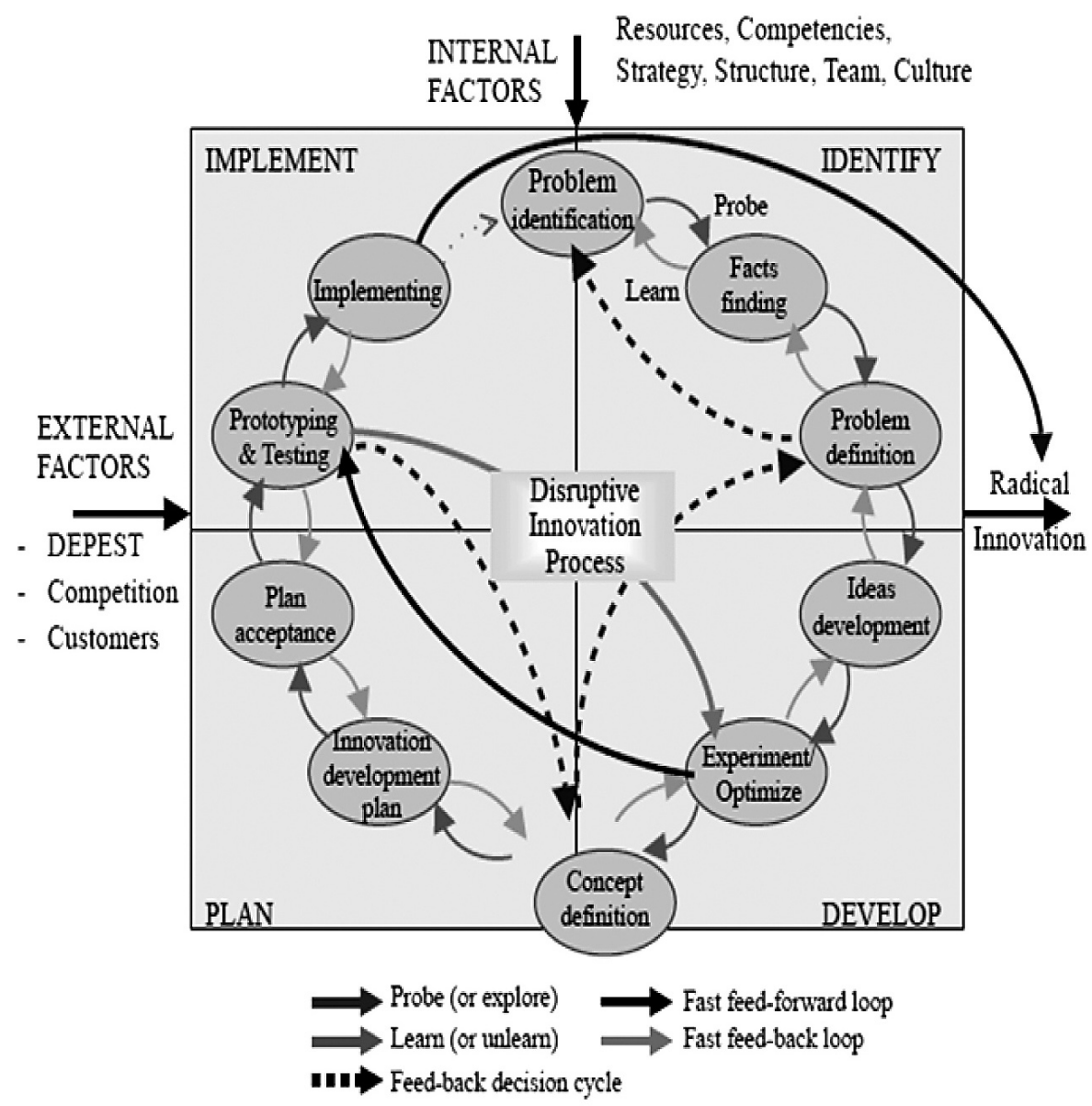

Fig. 3. Dynamic disruptive innovation process

Source: M. Assink (2006). 


\begin{tabular}{|r|l|}
\hline 1 & Analyze potential innovation idea identification sources \\
\hline 2 & Determinate consumer needs, desires and expectations \\
\hline 3 & Reduce ideas, by selecting the most simple and concentrated \\
\hline 4 & Start small \\
\hline 5 & Guide innovation as leader in particular segment \\
\hline
\end{tabular}

Fig. 4. P. Drucker`s scheme for innovation process

Source: R. Swaim (2010).

In marketing one of the most commonly used schemes is P. Kotler's innovation process model which is based on BAH model (Kotler, 1999). With his model P. Kotler claims that teh new product development starts with the company's vision. Then the following stages follow: new product's strategy, idea generation, idea testing, concept creation and testing, marketing strategy choice, business analysis, product development, test marketing, and commercialization (Figure 5).

Latvian researcher A. Abeltina distinguishes four stages for innovative operation as process - searching for a new idea and evaluation, development of a business plan, resource allocation, and established company's management (Figure 6) (Abeltina, 2008).

Defence Advanced Research Projects Agency (DARPA) is one of the most innovative companies in the USA. Thanks to its findings the internet, GPS, RISC cardiac, soundless aviation and cloud computing is available to and used by the mankind. The DARPA's previous managers E. R. Dugan and K. J. Gabriel states that DARPA practices slightly different aspects of innovation process in comparison with OECD or ones which offers management and marketing academic literature. There is unbeneficial gap between fundamental science researches and new product implementation. The authors of DARPA model insists that DARPA model is the only model that decreases this gap. In DARPA model there are 3 prerequisites determined and 4 functions that exist in Pasteur's quadrant. The terminology of Pasteur's quadrant was first introduced by D. E. Stock. It determines the sequence according to which scientific public findings help to solve actual and clearly formulated customer need. In Stock matrix

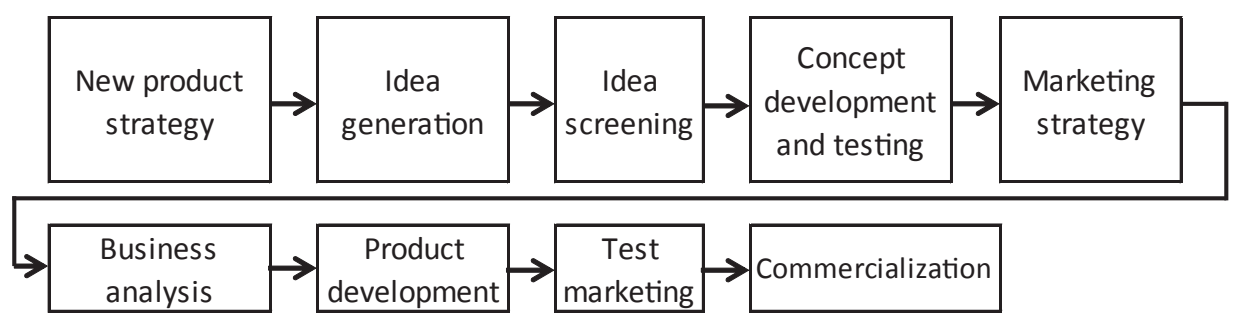

Fig. 5. New product development process (P. Kotler)

Source: P. Kotler (1999). 


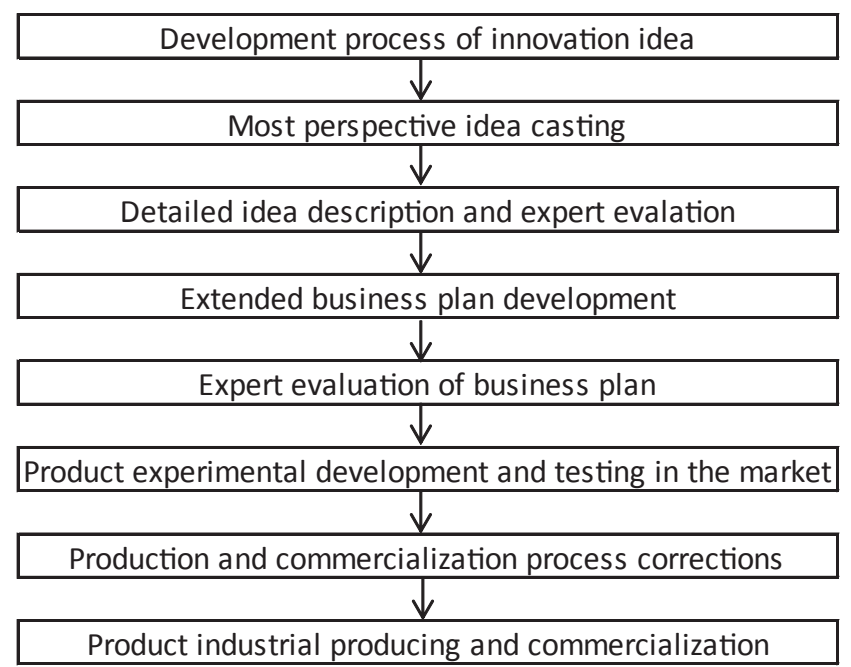

Fig. 6. A. Abeltina's Innovation process

Source: A. Abeltina (2008).

in addition to Pasteur's quadrant there are also Bora, Edison and unnamed quadrant (Figure 7) (Dugan, Gabriel, 2013).

Only a few organizations operate in Pasteur's quadrant. Quite rarely the innovation development process can be observed in this quadrant. It explains the low number of radical innovations coming from companies. Sometimes $R \& D$ department researches are performed in Bora quadrant, and in case of failure, their drop to unnamed quadrant find no

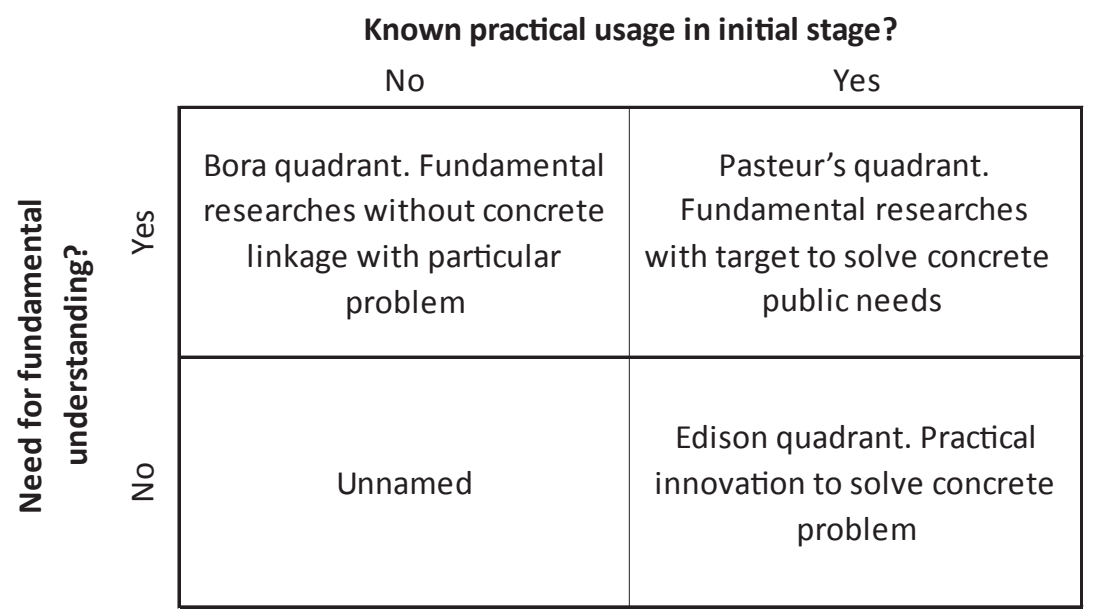

Fig. 7. Extended scientific research and consumer needs interaction matrix

Source: D. E. Stokes (1997). 
interest in science and no opportunities in commercialization. In most cases companies innovation investigation budgets are aimed to maintain the company's competitive advantage. This is the reason why BAH innovation process (Figure 8) starts with new product strategy which clarifies and provides guidelines for the further NPD process. The disadvantage of Pasteur's quadrant is a lack of guidelines. Results can decrease business performance even ruin it. Companies' innovation departments are not expected to perform researches that could potentially ruin the business. Therefore E. R. Dugana and K. J. Gabriel recommends companies to form small and independent organizational structures that focus on innovation process within the Pasteur's quadrant based on DARPA model. Three prerequisites of DARPA model are - ambitious objectives, short term project teams and independence from the institutions control. DARPA model includes 3 functions: identification of innovation idea, definition of project, and project development monitoring.

In DAPRA method project control is different from classical project management models that monitor certain border poles of a project. In Pasteur's quadrant projects require different project management approaches and a set of instruments requiring fast iteration and an easy, flowing planning process. The progress can be observed by monitoring iterations and the oncoming towards the goals, identifying project failure, revealing new opportunities or identifying the need for completely new technologies. Considering this it becomes understandable that obeying strict deadlines is not effective. E. R. Dugana and K. J. Gabriel points out that sometimes failure of a project could be the most effective tool for revealing new innovation. This aspect is also emphasized by $\mathrm{P}$. Drucker and a manager of $P \& G$ company, who prove that failure can be the greatest gain. If the team fails during innovation process then something has surprised them unprepared, and then it is the greatest finding. It should be anticipated in high risk innovation processes. DARPA method requires that if it happens, it is very important to allow the team to solve the issue further even though further investigation leads away from defined project deadlines. During the innovation process in Pasteur's quadrant, it has to be

\begin{tabular}{|c|c|c|c|}
\hline \multirow{4}{*}{ 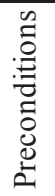 } & \multicolumn{3}{|c|}{ Ambitious targets } \\
\hline & \multicolumn{3}{|c|}{ Short term temporary team } \\
\hline & \multicolumn{3}{|c|}{ Independence from the supervising institutions } \\
\hline & \multicolumn{3}{|c|}{ Pasteur's Quadrant (TM) approach } \\
\hline 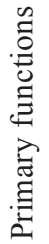 & $\begin{array}{l}\text { Identification of } \\
\text { innovation idea }\end{array}$ & $\begin{array}{l}\text { Defining the } \\
\text { Project }\end{array}$ & $\begin{array}{c}\text { Monitoring of } \\
\text { project } \\
\text { development }\end{array}$ \\
\hline
\end{tabular}

Fig. 8. DARPA innovation method

Source: R. E. Dugan and K. J. Gabriel (2013). 
remembered that the solution can also be unfound. Elastic and temporary teams are one of the most important components of DARPA project. Implementing short term projects, project leaders concentrate on results and do not worry about career growth which is important in innovation projects of Pasteur's quadrant. In addition to elasticity DAPRA method requires the project team's autonomy and independence from the management of a company. There can be many reasons why project control institutions do not accept innovative ideas. The authors of the paper illustrate this by the following situation from their practical experience with "Latvijas Balzams" innovation - unique amber vodka filtration, the development of which took more than 2 years and 50\% of the time was spent on the idea's coordination with the new product's development control commission. E. R. Dugana and K. J. Gabriel point out those radical innovations that usually are not in consensus with projects. DARPA method intends that along several indicated projects the teams choose those projects which they want to spend time on and work with them independently. Time reduction in DARPA method is possible by making permanent cooperation contacts with the industry experts - universities and research institutes, start-up enterprises, and freelancers. By using DARPA method "Motorola" has implemented 8 new innovation projects in 14 months, by involving more than 120 companies and institutions from 11 different countries. This aspect in DARPA method is linked with the practical usage of innovation theoretical ecosystems in applied environment.

The latest tendencies in innovation processes are to adapt quality management methods in innovation process. So far quality management methods have been methodically studied, developed and approbated more and longer than in innovation process. With the increased importance of innovations the significant problem clarifies - the inability to ensure innovation management in right time and quality in the early stage of innovation process. One of the recent researches K. Radeka looks to innovation process from the lean management perspective. Lean management in NPD creates right products in right time and place them for the right markets and for the right costs. Lean management implementation in NPD has the following strengths: more appropriate schedule planning, shorter development time, increased R\&D capacity, lower product costs, better NPD process management and control, opportunity to develop product that better fulfils the clients' needs by maximizing the received value and minimizing the costs. Lean management is dispersed into 4 value flows: client value flow (concept development), knowledge added value flow (analysis of opportunities), product design and testing value flow and manufacturing value flow. Lean management process is divided into the following stages: its provided opportunities, product design, design process, design testing and manufacturing (Figure 9) that are connected with product development for business decisions (Radeka, 2013).

K. Radeka considers the lean management model to be much better than Stage/ Gate model because of the level of elasticity. Even though this model is interesting, it has not been approbated and proven in practice. In addition, it does not explain how to come down to the concept and what the concept involves in itself, how 


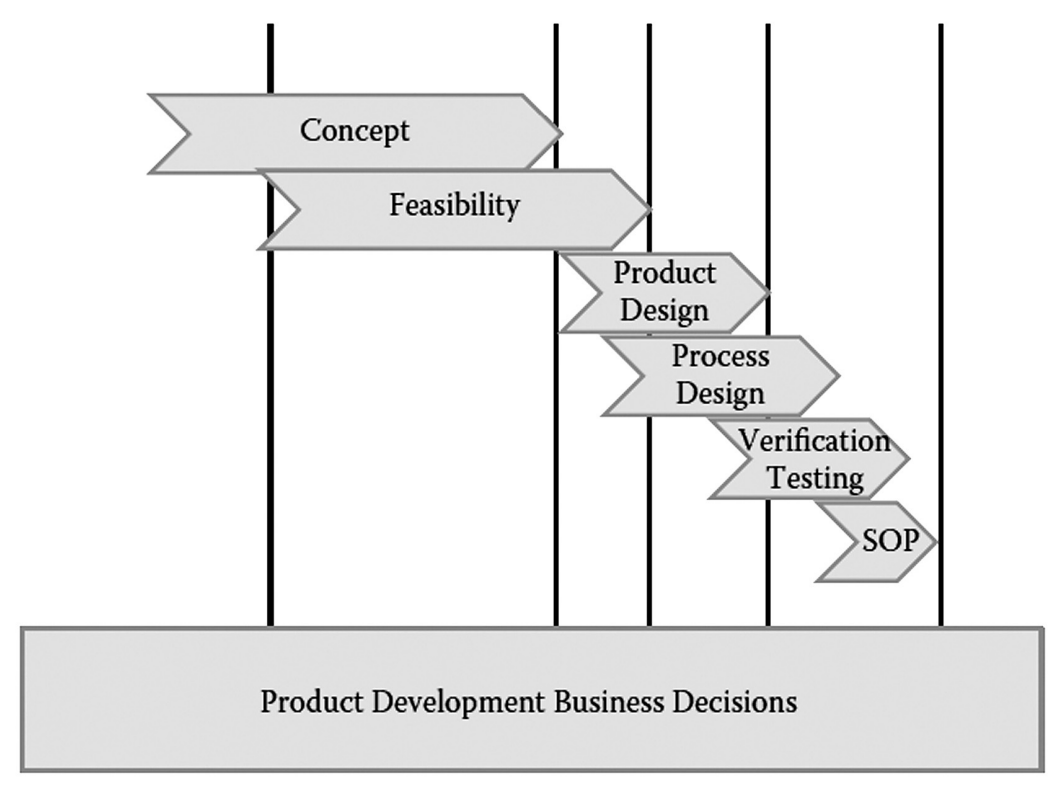

Fig. 9. A Lean Product development process

Source: K. Radeka (2013).

the communication process is organized. Perhaps it is possible to successfully implement lean management into Stage/ Gate model. Remark - new innovation process searches indicate that there is room for improvement in this process. By consolidating literature, interdisciplinary practice and empirical experience, $\mathrm{Au}$ thors of Paper have provided their model for more complete innovation process determination. The authors' model is based on value chain model, and fundamentals of G. Cooper Stage/ Gate scheme (Figure 10).

The model provided by the authors is focused on gradual added value increment during the innovation development process that is supported with important enterprise functions that are critical in innovation development. Each step involves an opportunity to suspend innovation process or return it to the repetitive recycling. The greatest difference between the authors' provided model and other models lies in the approaches of prioritizing the innovation sources, unlimited with the new product development or the company's strategy development by the following conclusions from DARPA model, linking the process of generating ideas with innovation information sources as a logical second step and emphasizing the company's supportive functions in the early stages of innovation development. The authors of the paper conclude that despite the existing discourses between the approaches, all scholars are in concord of the need to determin the information sources, which will guide the company forward to potential innovation. The authors of the paper will consolidate, analyse and systemize information sources, which include potential innovation idea for the company. 


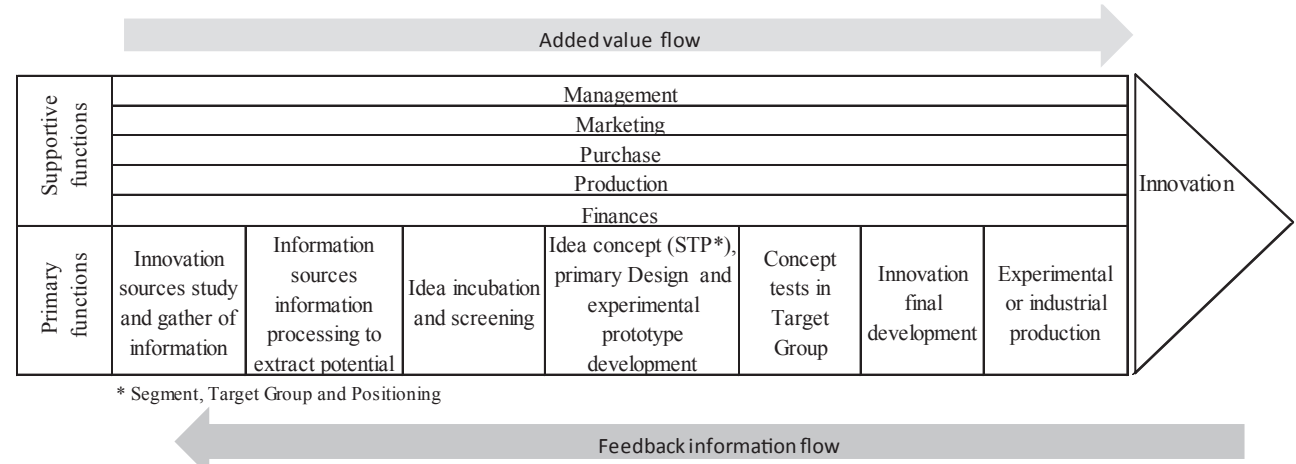

Fig. 10. Innovation value chain process

Source: the authors' construction based on the research findings

\section{Innovation idea identification information sources}

Identification of innovation idea commonly fallaciously are considered as generation of ideas, therefore associated with complicated, hardly controlled and manageable creative process, which doesn't conform with the known research methods. In its broadest meaning innovation idea identification means observing concrete, determinate information sources, concrete methods how to extract ideas out of them and screen for suitability to particular company needs. Innovation potential realization is strongly linked with research and consequent conclusions, and there is no place for mysterious creativity to be impacted. Sometimes companies mistakenly equalize the term $\mathrm{R} \& \mathrm{D}$ (Research and Development) with cthe omplete innovation process. $R \& D$ is related with research methodologies and can possibly be conducted within any of innovation processes. R\&D includes 3 activities, related with researches - based research, practical research and experimental development; conversely innovation is a much wider term, which includes the recognition of potential innovation, its screening, analysis, control, management, commercialization and functions' revision. In scientific literature, the stage of innovation idea identification in the innovation development process is less analysed compared to other stages. There exixts the term SIM (Structured Idea Management), which has been explored to determinate structured ideas management. 7 tasks have been marked out in that: 1) nomination of criteria, 2) preparation for the „brain storm” method 3) conduct of „brain storm”, 4) idea screening, 5) secondary revise of ideas in working group and ideas ordering after priorities 6) revision of work tasks, 7) final ordering. The authors of the paper evaluate it as a generic scheme, which draws the use of "brainstorm" and idea management after that, but is only one part out of other opportunities to approach systematically to innovation ideas identification. The authors of the paper devide the innovation idea process in 2 sections - information ideas identification and information processing methods - in order to extract innovation idea out of them (Figure 11). 


\section{Potential innovation ideas}

\begin{tabular}{|l|c|}
\hline \multicolumn{2}{|c|}{ Information sources processing methods with target to extract potential innovation idea } \\
\hline Quantitative methods & Qualitative methods \\
\hline
\end{tabular}

\begin{tabular}{|l|l|l|}
\hline \multicolumn{3}{|c|}{ Information sources of potential innovation idea identification } \\
\hline Company internal environment information sources & Company external environment information sources & Hybrid sources \\
\hline
\end{tabular}

Fig. 11. Innovation ideas identification process scheme

Source: the authors' construction based on the research findings

Further in the paper the first step of the process will be inspected. The authors allot information sources within external, internal environment and hybrids, which rise out of new innovation ecosystems (Baker, Hart, 2008).

The main aim of the innovation ideas identification stage is to develop enough ideas so that a company could screen and select the most suitable ones in order to reach its targets. Innovation identification sources are situated in the company's internal, external and combined (hybrids) environments.

\subsection{Companies internal information resources}

P. Kotler highlights that many new innovation ideas should be gathered within the company, by exploring formal and informal conducts (Kotler, Amstrong, 2006).
Engineers, scientists, designers, production staff in the company, the ones who manage the company's operation area, are delighted to provide their ideas substantially as their regular contribution to company. Management, as well can participate in the innovation development by providing their ideas. P. Kotler remarks, that the company "Toyota" from internal environment information sources gather more than 2 million potential innovation ideas.

P. Drucker has singled out the importance of internal analysis of the existing sales data. Meanwhile he highlights that innovation ideas start from 7 sources' analysis, 4 of which are related with opportunities in recent industry or entrepreneurship (Figure 12) (Swaim, 2010). The authors of this reserach oppose that the highlighted sources are only 4 , the rest are expert methods targeted to extract

\begin{tabular}{|r|r|r|l|}
\hline \multicolumn{2}{|c|}{ Opportunities in recent industry } & \multicolumn{2}{c|}{ Opportunities outside recent industry } \\
\hline 1 & Unexpected success or failure & 1 & Changes in Demographics \\
\hline 2 & Incongruity & 2 & Changes in social economics perceptions \\
\hline 3 & Needs of Process & 3 & New knowledge \\
\hline 4 & Changes in Industry or market structures & \multicolumn{2}{|l}{} \\
\hline
\end{tabular}

Fig. 12. Innovation idea identification sources

Source: R. Swaim (2010). 
information out of those information sources. The four sources for potential innovation idea identification mentioned by P. Drucker are: 1) company's internal data quantitative research; 2) company's internal processes analysis by any of quality management methods, 3) quantitative research of demographic data dynamics and 4) latest scientific discoveries and Patents content analysis. The others, P. Drucker mentioned, are expert methods.

The same imprecision is suggested by other authors, who indicate and approve that the low level of scientific investigation has been done behind the exploration of innovation idea identification sources.

Employees of the company. The majority of investigators highlight employees as the main source of potential innovation ideas of the company. Employees of the company have the best knowledge about the company's operative area, because they are the most involved in the company's processes. Employees have ideas what should be done better, and how it could be improved, and what could be resigned at all. Very often one can observe a situation, when employees initiate innovative ideas and far then a few managers who are ready to listen to them. Employees have outstanding ideas, how to solve the company's problems pointing out the needed innovations. By inspiring the company employees to submit their ideas, beside the support of their development the company can significantly increase successful innovations in their entrepreneurship activities. The authors point out the following 3 categories of employees important for the innovation idea identification: management of a company, leading experts and sales force.

The company business partners, suppliers or distribution partners are as rich environment for potential innovation ideas. Suppliers can inform about the latest technologies, concepts, technics or materials, which can be embraced by developing a new product or service. Useful information can be gathered from industry professional editions, exhibitions, government agencies, new product consultancy companies, seminars, advertising agencies, marketing research companies, universities, Science Parks and scientists. The existing product portfolio analysis is the important resource, especially unexpected success or failure in it. Often slight changes in any of them can guide to new radical innovation with new products and brands. For example, the company "Unilever" in 1930 added detergent ingredients for regular soap, therefore innovating forward to powder as a new category (Trot, 2012).

\subsection{Companies external information sources}

Companies' competitors, their production or services are significant and abundant source of potential innovation ideas information. Through extended analyses of competitors' products, focusing not only on copy, imitation or successful adaption strategies, but also on potential improvement, there is good opportunity to gather important information. Through competitors' analyses it is important to analyse the factors and components, which make them so successful, diving deep in the true needs and desires of consumers and customers. By implementing the desired improvements, companies could gain particular and measurable competitive advantage over their most successful competitors. P. Kotler mentions that around $30 \%$ new products of companies 
are developed after teh analysis of competitors' production new products. Customers' and consumers' researches are one of the most explored innovation potential sources for companies to explore. Besides, well conducted by traditional marketing research methods, one important source is the company customers' clients articulated desires. Instead of listening to their clients, companies conduct expensive consumer researches. Usually clients are ready to express their needs and desires free of charge and delightful that somebody of the supplier company listens to them. The clients of the company almost always know what they want, and commonly they have innovative ideas, how their needs could be served the best with new products or services. After researches P. Kotler concludes (Kotler, Amstrong, 2006 ) that $28 \%$ of new products are client inspired, by careful listening and observing. There is recommendation for the company to conduct research on clients so that to gather information about the clients' needs and desires. Through their analysis there is a possibility to identify potential innovation ideas directly serving the clients and contributing to the company almost immediately. Moreover, gathering information about the clients' desires and needs, as much important is to understand their complaints and questions. By studying the clients' complains and problems, P. Kotler suggests to initiate a working group of the company's production department, and motivate them to solve clients' problems in an extraordinary way. P. Kotler marks, that the companies "GE", "Sony", "Toyota" and other innovative ones are organizing engineer meetings with their clients for innovation inspiration. As much ideas can be sourced through clients' observation. The recent innovation leader of "Sony” Akio Morita claimed that despite the marketing departments' research the major and constant focus should be laid on consumer researches as consumers' ability to articulate their desires is limited; the same way believed the previous leader of „Apple" Steve Jobs (Trott, 2012). A. Morita found that public is uncertaint of what is available, and the company must guide the consumer and present the consumer his desires and need states. Companies, which will discover needs and desires of the future consumer, will be sustainably successful in the future. A. Morita supposes that companies must constantly challenge recent markets, consumers and their recent needs. The companies "IBM" and "Xerox" have learned that lesson in practice: the today's consumer might not be the future's consumer. The scientists G. Hamel and C. K. Prahalad have visually demonstrated the area of unarticulated consumer needs, and highlighted high risk probability, if the company doesn't take it into account (Figure 13.) (Trott, 2012).

Trends. Micro and macro trends play a significant role in the potential innovation idea identification. Trends are more significant and permanent determinates of consumer's future needs, versus seasonal up-downs. Trends reveal the curtain of the future by providing a lot of opportunities. P. Kotler as a sample highlights the movement of fitness trend, which slowly but permanently changed a lot of industries surrounded - cosmetics, food, house hold, leisure time activities, food beverages, farming, clothing and other industries. As "Impact" - the leading market research professional magazine in the USA market - reported, one of the fastest growing alcoholic beverages brands 


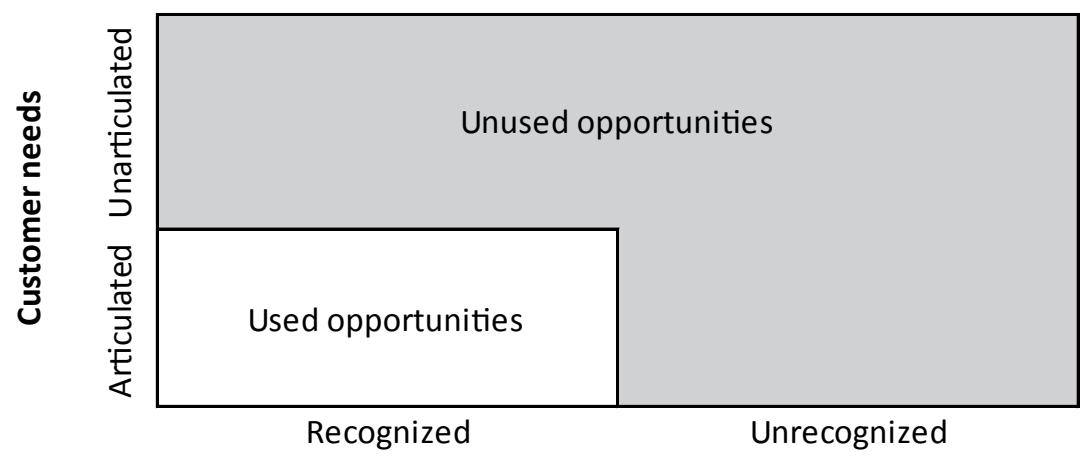

Fig. 13. New consumers gathering in the future

Source: G. Hamel and C. K. Prahalad (1994).

in 2012 were "Skinny Girls", low calorie alcoholic cocktails. According to P. Kotler, macro trends are large social, political and technological processes, which are embodied in 7-10 years period, and they do valuable investigation during the studies of information gathering for potential innovation ideas. Innovation program is much more successful, when aligned with micro and macro trends, not only concentrated on new needs and market developments, according to P. Kotler (Kotler, Keller, 2006).

\subsection{Hybrid information resources for innovation determination}

Open innovation methods are the usage of crowd power. In scientific literature more appears information of open innovations. Till the millennium innovation process in the companies was closed and confidential, but now more and more companies initiate open innovation process, asking outside input in challenges that the company faces. There is several crowd involvement dimensions: a) broad involvement open innovation competition, which is at a large scale available to any interest, named crowd contests; b) innovation competition, which is meant for particular cluster groups, named collaborative communities. Kevin J. Boudreau and Karim R. Lakhani (Boudreau, Lakhani, 2013) without the two previously mentioned, identifies another 2 dimensions for open innovations: complementors and labour market (Table 1). Crowd complementary function is to find innovative application to the existing product or brand by developing platforms to other innovative solutions. For example, application to smartphones or other solutions for Google is considered as crowd complimentary innovation. The crowd labour market dimension involves potential employee market by challenging the existing labour market system, when employees are contracted on long-term bases. Several on-line companies have opened data bases of concrete human resources services. Those can be explored and hired temporary or permanently by any company or project office. That type of crowd innovations rapidly impacts and facilitates "start-up" company entrepreneurship, any innovation projects 
Open innovation dimensions by using power of crowd

\begin{tabular}{|c|c|c|c|}
\hline & Purpose & Challenges & Best Use \\
\hline Contests & $\begin{array}{l}\text { Generating high-value } \\
\text { solutions to complex } \\
\text { or novel problems } \\
\text { through large-scale and } \\
\text { diverse independent } \\
\text { experimentation }\end{array}$ & $\begin{array}{l}\text { The problem must be } \\
\text { generalized and stripped of } \\
\text { company-specific details }\end{array}$ & $\begin{array}{l}\text { Highly challenging technical, } \\
\text { analytical, and scientific } \\
\text { problems; design problems; } \\
\text { creative or aesthetic projects }\end{array}$ \\
\hline $\begin{array}{l}\text { Collaborative } \\
\text { communities }\end{array}$ & $\begin{array}{l}\text { Aggregating a large num- } \\
\text { ber of diverse contributi- } \\
\text { ons into a value-creating } \\
\text { whole }\end{array}$ & $\begin{array}{l}\text { The crowd lacks the shared } \\
\text { culture and cohesiveness of } \\
\text { a company, making it har- } \\
\text { der to control; intellectual } \\
\text { property can't be protected }\end{array}$ & $\begin{array}{l}\text { Customer support communi- } \\
\text { ties; wikiw; open-collabora- } \\
\text { tion projects for information } \\
\text { and software products with } \\
\text { complementary assets inside } \\
\text { the firm; FAQs }\end{array}$ \\
\hline Complementors & $\begin{array}{l}\text { Encouraging innovative } \\
\text { solutions to users` many } \\
\text { different problems with } \\
\text { your core product }\end{array}$ & $\begin{array}{l}\text { It can be technological- } \\
\text { ly daunting to provide } \\
\text { access to the functions and } \\
\text { information in the core } \\
\text { product while protecting } \\
\text { your assets }\end{array}$ & $\begin{array}{l}\text { Open operational, product, } \\
\text { or marketing data initiatives; } \\
\text { content mashups; apps }\end{array}$ \\
\hline Labor Markets & $\begin{array}{l}\text { Efficiently and flexibi- } \\
\text { lity matching tallent to } \\
\text { discrete tasks }\end{array}$ & $\begin{array}{l}\text { Identifying which pro- } \\
\text { blems to farm out and who } \\
\text { in the organization will } \\
\text { manage the labor pool may } \\
\text { be difficult }\end{array}$ & $\begin{array}{l}\text { Well-extablished categories } \\
\text { of work that can be clearly } \\
\text { described and evaluated; hu- } \\
\text { man computation; repeated } \\
\text { tasks }\end{array}$ \\
\hline
\end{tabular}

Source: K. J. Boudreau and K. R. Lakhani (2013).

in the settled companies, without enough resources for innovation departments.

In Figure 14 the authors of this paper offer the illustration of the main conclusions of the research. Consolidating scientific literature and different approaches, combined with empirical practice, it has been concluded that there are 11 sources of information, internal, external and hybrid, which the company can use for the analysis trying to identify potential innovation idea.

\begin{tabular}{|c|c|c|}
\hline \multicolumn{3}{|c|}{ Innovation idea identification sources in the company } \\
\hline Internal Sources & $\begin{array}{c}\text { External Sources } \\
\end{array}$ & Hybrid sources \\
\hline 1 Employees (management, sales force, experts) & \begin{tabular}{l|l|}
1 & Consumers and Customers \\
\end{tabular} & \begin{tabular}{l|l}
1 & Crowd Energy \\
\end{tabular} \\
\hline 2 Business Partners & 2 Competitors & \\
\hline \begin{tabular}{l|l}
3 & Existing products or services portfolio \\
\end{tabular} & \begin{tabular}{l|l|}
3 & Trends \\
\end{tabular} & \\
\hline & \begin{tabular}{l|l}
4 & Changes in Demographics \\
\end{tabular} & \\
\hline & \begin{tabular}{l|l}
5 & New Knowledge in Technology and non- Technology \\
\end{tabular} & \\
\hline & \begin{tabular}{l|l}
6 & Changes in Industry and market structures \\
\end{tabular} & \\
\hline & 7 Patent data bases & \\
\hline
\end{tabular}

Fig. 14. Innovation idea identification sources in the company

Source: developed by the authors of the paper based on the research findings. 


\section{Conclusions, proposals, recommendations}

Innovation is key a driver of contemporary economy. A developed and effective innovation process is key important for the company to ensure sustainable competitiveness. There is significant focus in scientific research on innovation influencing factors in macro environments vs. direct influencing activities in micro environment - the company, which actually develops particular innovation. A lot of various approaches to innovation process are available both in scientific and practical environment. Variations in processes are both - substantial and gradient. The details of the process are highlighted as extremely important in delivering the most valuable innovation process. There is reserved approach from scientists' perspective to the very start of innovation process - determination of innovation idea. Concepts and researches of this innovation process part are blurred and uncertain, the majority of it deducted to the method "brain storm", creativity and abstract ideas generation. The authors of the paper by consolidating theoretical conduction and empirical experience propose a new, gradually improved innovation process, based on the most approbated Coopers' Stage/ Gate model, enriched with the latest discoveries in quality and logistics management, and a clear and highlighted focus on the identification of innovation idea through deliberated information sources. The authors have gathered and systemized information of 13 concrete sources of potential inclusion of innovation idea, based on various scientists' essays about the theme, including the most recent approaches both on scientific literature and practical environment. The gathered and systemized information about potential innovation sources are half process in determining innovation idea. Specific information processing methods should be used, to extract potential innovation idea out of those information sources, which are recommended by the authors for further research. It is recommended to start to approbate the proposed and improved innovation process scheme, by highlighting the innovation idea identification through scientific and determinate approach, avoiding the mysterious and uncontrolled creativity approach.

\section{References}

1. Abeltina, A. (2008). Inovacija - XXI gadsimta fenomens. Riga: SIA „Biznesa augstskola Turiba“. 61. lpp.

2. Assink, M. (2006). Inhibitors of disruptive innovation capability: a conceptual model. European Journal of Innovation Management, Vol. 9 No. 2, Emerald Group Publishing Limited, pp. 215 233. DOI: $10.1108 / 14601060610663587$

3. Baker, M. J., Hart, S. (2008). The Marketing Book 6th edition, Elsevier, Great Britain.

4. Bernstein, B., Singh, P. J. (2006). An integreted innovation process model based practices of
Australian biotechnology firms. Technovation, Vol. 26 No. 4-5, pp. 561-572. DOI: 10.1016/j. technovation.2004.11.006

5. Boudreau, K. J., Lakhani, K. R. (2013). Using the Crowd as an Innovation Partner, Harvard Business Review, reprint R1304C, April 2013.

6. Davila, T., Epstein, M. J., Shelton, R. D. (2013). Making Innovation Work., Pearson Education, Inc. FT Press.

7. Dugan, E. R., Gabriel, K. J. (2013). "Special Forces" Innovation: How DARPA Attacks Problems. Harvard Business Review. 
8. Gopalakrishnan, S., Damnpour, F. (1997). A review of innovation Research in economy, sociology and technology managment, Omega, The International Journal of Managment Science.

9. Hamel, G., Prahalad, C. K. (1994). Competing for the future, Harvard Business Review, Vol. 72, No. $4,122-8$.

10. Inovacijas un Latvijas tautsaimniecība (2011). LU AA, Riga.

11. Kotler, P. (1999). Principles of Marketing, Prentice Hall Europe, New Jersey, USA, pp. 607.

12. Kotler, P., Amstrong, G. (2006). Principles of Marketing. Practice-Hall India, p. 768.

13. Kotler, P., Keller., K., L. (2006). Marketing Managment, 12th edition, Pearson Prentice Hall, New Jersey.
14. OECD. (2005). Oslo Manual - Guidlines for collecting and interpreting innovation data $3^{\text {rd }}$ edition.

15. Radeka, K. (2013). Mastery of Innovation, A Field Guide to Lean Product Development, CRC Press, Taylor \& Francis Group, New York,.

16. Stokes, D. E. (1997). Pasteur's Quadrant: Basic Science and technology innovation, Brookings Institutional Press.

17. Swaim, R. (2010). The Strategic Drucker, Singapore; Ltd. A Wiley Imprint on behalf of Jossey -Bass.

18. Trott, P. (2012). Innovation Management and New Product Development, Fifth Edition, FT Prentice Hall, Finacial Times, Pearson.

The paper submitted: May 13, 2014

Prepared for publication: June 10, 2014

\section{Anda BATRAGA, Liga BRASLIN̦A, Kaspars VIKSNE INOVACIJOS IDÉJŲ IDENTIFIKAVIMAS IR INOVACIJOS VYSTYMO PROCESAS}

\section{S a n t r a u k}

Inovacijos tapo vienu iš ekonomikos augimo variklių, kur labai svarbus vaidmuo tenka mokslui ir išsilavinusiems žmogiškiesiems ištekliams. Ankstesniuose ekonominiuose laikotarpiuose inovacijos buvo ekonominio vystymosi pagrindas, tačiau dabar jos tapo vienu pagrindinių ekonominio augimo veiksnių. Naujausiuose mokslininkų darbuose pristatomas "inovacijų ekonomikos" terminas. Nepaisant didelès inovacijų svarbos ekonominiam augimui, nepakankamai ištirta sritis yra inovacijų vystymas mikroaplinkose. Logistikos grandinių ir sistemos vystymas sparčiai padejo ịmonèms sumažinti savo išlaidas. Pradejus tirti ir analizuoti inovacijų sistemas, jų sudetines dalis ir veiksnius darančius ịtaką, prieita išvados, kad inovacijas sudaro inovacijų šaltiniai, idejų apdorojimas ir koncepcijos vystymas. Nepaisant temos populiarumo, daugelyje imonių dažniausiai naudojami informacijos šaltiniai inovacijų identifikavimui yra minčių lietus ir intuicija. Mokslinèje literatūroje egzistuoja gan ribotas požiūris ị inovacijų šaltinius, kadangi daug neaiškių komponentų paliekama "kūrybiniam marketingui". Straipsnyje pristatoma pastaruoju metu taikoma inovacijų vystymo proceso teorinè apžvalga sutelkiant pagrindinị demesị i patị pirmąji etapą - inovacijų idejų informacijos šaltinius, todèl išsamiau pristatyti identifikuoti informacijos šaltiniai ir pateikta jų klasifikacija. Straipsnio tikslas yra identifikuoti ir išanalizuoti mokslininkų pasiūlytus ir praktikoje taikytus inovacijų proceso modelius, daugiausia dèmesio skiriant informacijos šaltinių inovacijų idejų identifikavimui nustatyti bei, remiantis gautomis išvadomis, pateikti patobulintą inovacijų proceso modelị ir galimų informacijos šaltinių sintezę. Inovacijų idejos identifikavimo šaltiniai yra susiję su visu inovacijos vystymo procesu imoneje, todèl straipsnio autoriai analizuoja visą procesą, akcentuojant jo pradinius etapus. Dauguma mokslinèje literatūroje išnagrinètų inovacijų procesų pradedami nuo idejos generavimo, dažniausiai akcentuojant vieną iš inovacijos idejos identifikavimo informacijos šaltinių, tačiau straipsnyje detaliai išnagrinèti ịvairioje mokslinèje literatūroje pateikti informacijos šaltiniai. Straipsnio autoriai, jungdami mokslineje literatūroje pateikiamus skirtingus požiūrius su empirine praktika, padarè išvadą, kad yra 11 informacijos šaltinių - vidiniai, išoriniai ir hibridiniai, kuriuos įmonè gali naudoti siekiant identifikuoti galimą inovacijos idèją. Straipsnio autoriai išanalizavo ir susistemino visus 11 šaltinių ir išryškino tolimesnes galimų tyrimų sritis. Darbe naudoti tyrimo metodai yra susijusios literatūros reliaciné turinio analizè, loginé analizé ir sintezè, lyginimas ir apibendrinimas, dedukcija ir konceptualizavimas, empirinis tyrimas. Siekiant atlikti tyrimą buvo taikyti dokumentų analizé, grupavimo ir grafinès analizės metodai. 